\title{
A new species of philometrid parasite (Nematoda, Philometridae) and histopathological lesions in juvenile whitemouth croakers, Micropogonias furnieri (Desmarest)
}

\author{
2 M M Montes ${ }^{1}$, S E Plaul ${ }^{2}$ and S R Martorelli ${ }^{1}$ \\ 1 Centro de Estudios Parasitológicos y Vectores (CEPAVE), Consejo Nacional de Investigaciones Científicas y \\ Técnicas, Universidad Nacional de La Plata (CCT-La Plata-CONICET-UNLP), La Plata, Buenos Aires, Argentina \\ 2 Laboratorio de Histología y Embriología Descriptiva, Comparada y Experimental, Facultad de Ciencias \\ Veterinarias, Universidad Nacional de La Plata, La Plata, Buenos Aires, Argentina
}

\begin{abstract}
A new species of nematode parasite, Philometroides tabieli sp. nov. is described. The juvenile whitemouth croaker, Micropogonias furnieri Desmarest, was collected during the spring and summer of the years 2008-2010 from estuarial environments of Argentina. During investigations of the parasite fauna a nematode encapsulated in the musculature of the operculum was found. The nematodes were removed from the host's muscle tissue and slidemounted in lactophenol solution to clarify the specimens. Opercular muscle with the parasite was processed for histopathological examination. Philometroides tabieli sp. nov. can be identified by the location of gravid females in the host, presence of anterior oesophageal bulb, bosses on the surface of the body, presence of transversal mounds and 14 cephalic papillae in two circular rows. The pathogenicity of the parasite is low in the natural environment, but lesions are consistent with a chronic process. The appearance of caseous necrosis suggests the presence of a locally acting substance. Philometroides tahieli sp. nov. is the second species of this genera described from brackish waters, and since the discovery of Philometroides
\end{abstract}

Correspondence M M Montes, Centro de Estudios Parasitológicos y Vectores (CEPAVE), Consejo Nacional de Investigaciones Científicas y Técnicas, Universidad Nacional de La Plata (CCT-La Plata-CONICET-UNLP). Calle 122 y 60 s/n. CP 1900, La Plata, Buenos Aires, Argentina (e-mail: martinmiguelmontes@gmail.com)

The first two authors contributed equally in carrying out the manuscript. maplestoni in 1928, is the first species of this genus recorded for South America.

Keywords: caseous necrosis, histopathological study, Micropogonias furnieri, Philometroides.

\section{Introduction}

The genus Philometroides Yamaguti, 1935 includes 34 species of nematode parasites of worldwide distribution (Moravec 2006; Moravec \& de Buron 2013; Moravec et al. 2015), despite this, few are known from South America, and only one species Philometroides maplestoni Travassos, Artigas \& Pereira 1928 has been described from Brazil (Travassos et al. 1928).

Philometrid nematodes are haematophagous and represent severe economic impacts on fish farms (Moravec 2006). They are highly pathogenic to their hosts producing a fish disease called philometroidosis (Schäperclaus 1992; Moravec \& de Buron 2013). Deardorff et al. (1986) and Kuroda et al. (1991) have reported accidental infection in humans resulting from the consumption of raw or undercooked fish.

The whitemouth croaker, Micropogonias furnieri (Desmarest), Scianidae, is distributed from Veracruz, Mexico $\left(20^{\circ} 20^{\prime} \mathrm{N}\right)$ to El Rincón, Argentina $\left(41^{\circ} 00^{\prime} S\right.$ ) (Cousseau \& Perrotta 2004) and is economically important in Argentinian, Uruguayan and Brazilian fisheries (Otero \& Ibañez 1986; Haimovici, Pereira \& Vieira 1989; Lasta \& Acha 1996; Norbis \& Verocai 2005) being the second most abundant species (Carozza et al. 2004). Since

\begin{tabular}{|c|c|c|l|l|l|}
\hline \multirow{2}{*}{0} & J F D & \multirow{3}{*}{ WILEY } & Dispatch: 6.11.15 & CE: Keerthana \\
\cline { 2 - 3 } & Journal Code & Manuscript No. & & No. of pages: 7 & PE: Rathi \\
\hline
\end{tabular}


2003 the number of juveniles caught has increased due to the exploitation of nursery areas near the coast (Carozza \& Hernández 2014).

During survey investigations of the parasite fauna of juvenile whitemouth croakers in brackish waters of Samborombón Bay (Buenos Aires, Argentina), a nematode parasite encapsulated in the musculature of the operculum was found. Closer examination revealed that this female nematode was a new species.

The purpose of this study is to provide a description and illustration of female adult specimens of a new species of Philometroides, recorded for the first time from Argentina and the second time from brackish waters. In addition, histopathological lesions in the muscular tissue of the operculum are described.

\section{Materials and methods}

Juvenile whitemouth croakers were collected during the spring and summer of 2008-2010 at two estuar-

3 ine environments of Argentina (Fig. 1, Table 1). The first estuarine environment was located in Samborombón Bay (site A = Ajó River $\left(36^{\circ} 22^{\prime} \mathrm{S}\right.$; $56^{\circ} 42^{\prime} \mathrm{O}$ ) and the second environment, the Bahía Blanca estuary (site B), located in the south of Buenos Aires province $\left(39^{\circ} 11^{\prime} \mathrm{S} ; 62^{\circ} 03^{\prime} \mathrm{O}\right)$.

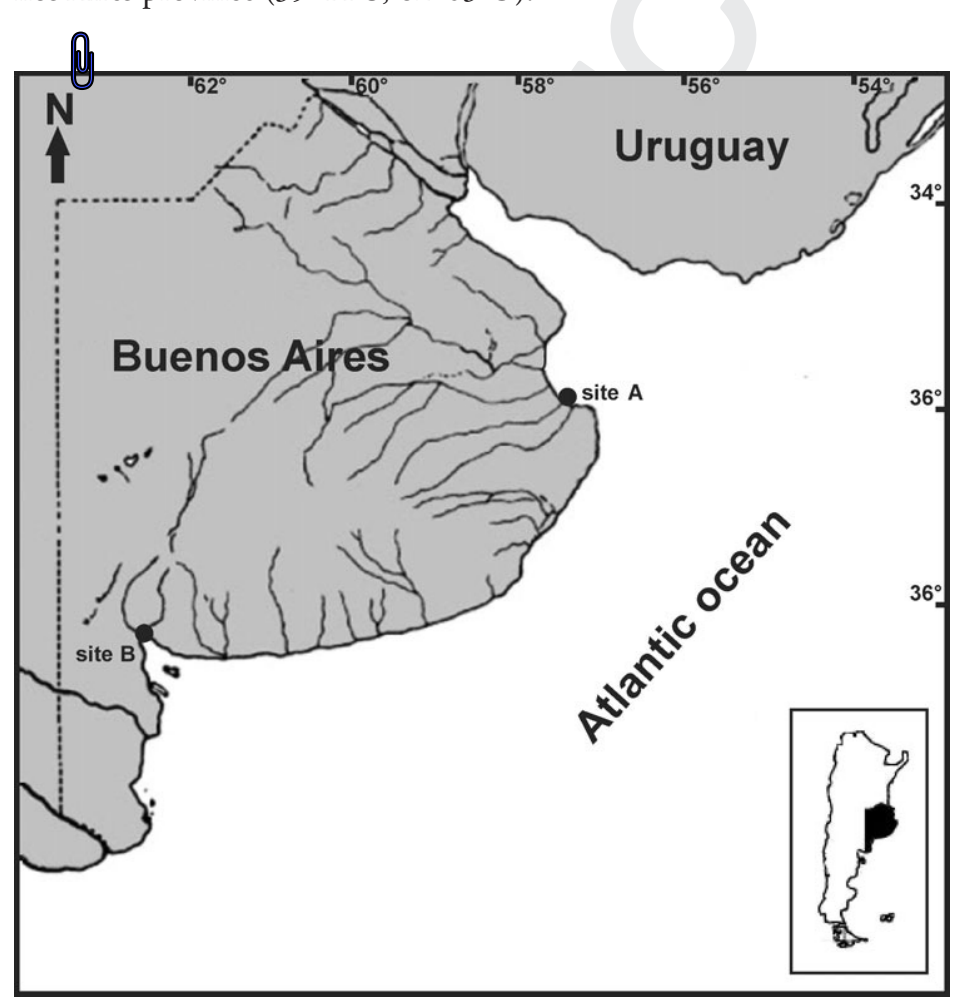

Figure 1 Sampling sites for collection of juvenile whitemouth croakers (Micropogonias furnieri) in the La Plata and Bahia Blanca estuaries, Buenos Aires province. Site $\mathrm{A}=$ Salado River, Relief channel, $B=$ Ajó River, $G_{\mathbf{\Lambda}}=$ Bahía Blanca estuary. 
Table 1 Number of juvenile Micropogonias furnieri per size collected in sample sites

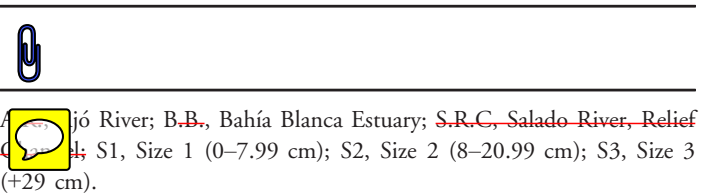

\section{Results}

Family Philometridae Baylis \& Daubney, 1926 Philometroides tabieli sp. nov. (Figs 2-3)

Description. Gravid female: (measurements of 5 gravid specimens). Specimen with body elongated (29.8-31.4 mm long, $0.42-0.55 \mathrm{~mm}$ wide), reddish-coloured, tapering at both ends (Fig 2a). Almost entire body covered by numerous, irregular and small cuticular bosses (Fig. 2b,d). Embossment
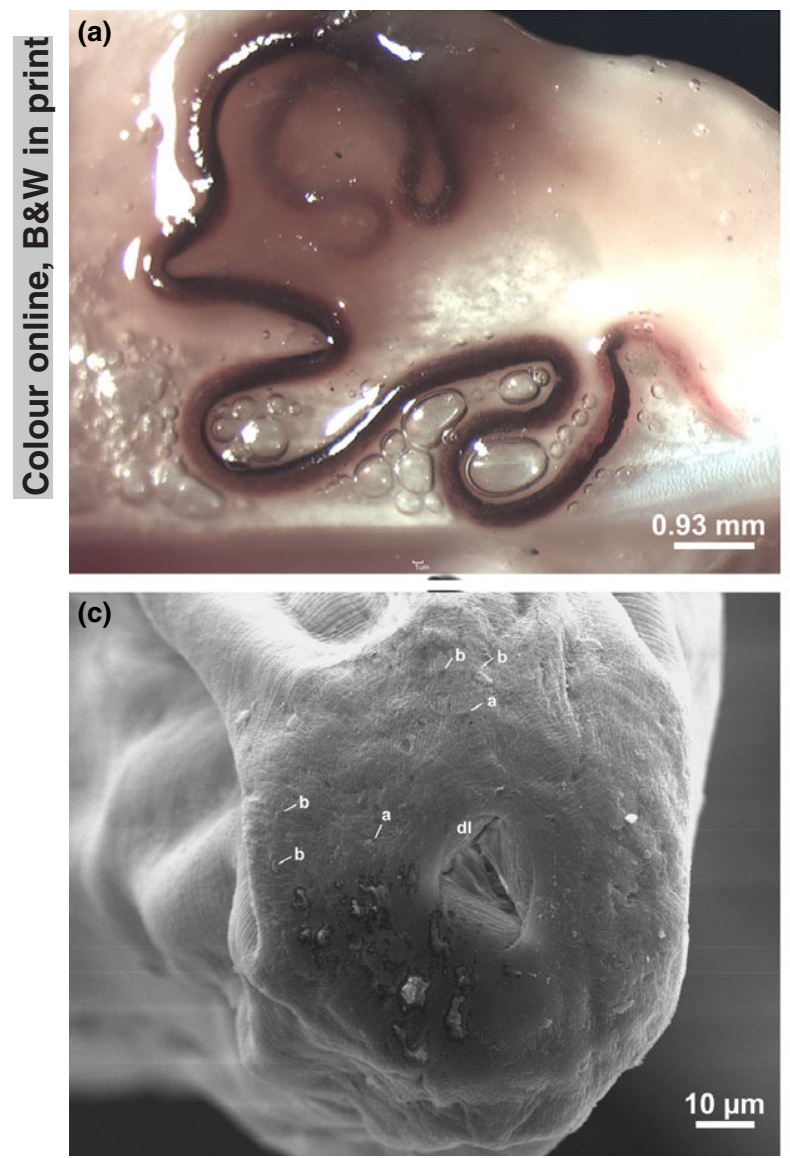

starts at level of caudal third of oesophagus with small bosses (5-7 $\mu \mathrm{m}$ high) which become bigger in the middle of the body (10-13 $\mu \mathrm{m}$ high) and decrease in size towards the caudal end $(8-11 \mu \mathrm{m}$ high). Cephalic end rounded with six papillae in an inner circle and eight papillae, forming four pairs, in an outer circle (Figs 2c and 3b). Oral aperture small, circular-shaped surrounded by three oesophageal lobes that protrude outside the mouth (Fig. 2c). Oesophagus anterior end enlarged near the mouth (Fig. 3a) to form a small muscular bulb $(0.06 \mathrm{~mm}$ long and $0.05-0.08 \mathrm{~mm}$ wide) and opens into the intestine through a valve. Oesophagus (including the muscular bulb) $1.15-1.36 \mathrm{~mm}$ long, representing $38-42 \%$ of body length. Oesophageal gland extends from level of nerve ring to the end of oesophagus. Nerve ring encircling cranial end of oesophagus, distance $160 \mu \mathrm{m}$ from the upper body to nerve (Fig. 3a). Intestine brown, placed

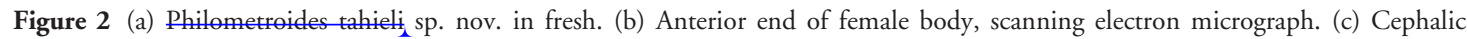
end of female, scanning electron micrographs. (d) Structure of cuticle with bosses and transversal mounds. a, inner circle of papillae; b, external circle of papillae; $\mathrm{dl}$, dorsal anterior lobe of oesophagus. 
(a)

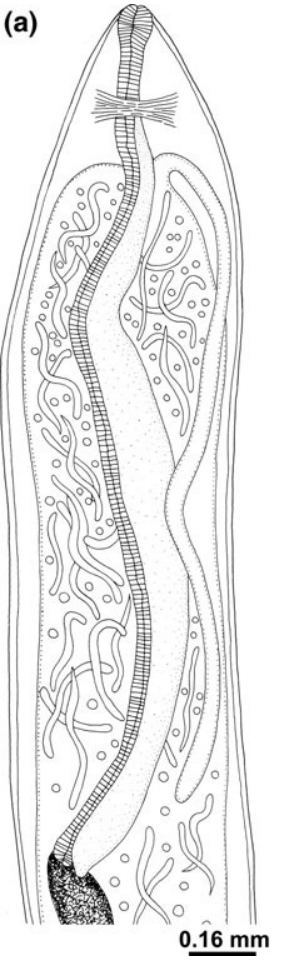

(b)

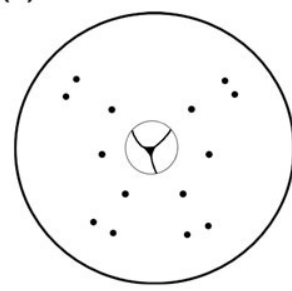

(d)

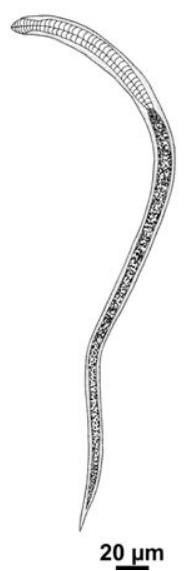

(c)

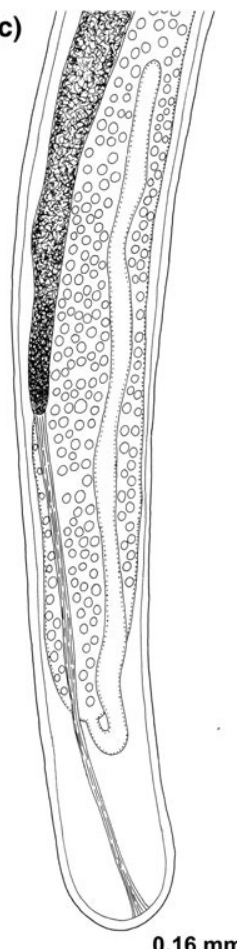

Figure 3 (a) Philomides nov., anterior end of gravid female, lateral view. (b) Cephalic end of gravid female, apical view. (c) Caudal end of gravid

female. (d) Larva from uterus, lateral view.

laterally to the uterus, atrophied and attached by a ligament $(0.79 \mathrm{~mm}, n=1)$ to ventral body wall (Fig. 3c). Ovaries (1.07-1.08 mm long $0.04 \mathrm{~mm}$ wide) situated near the cranial and caudal ends. Uterus highly developed, extends from the third caudal part of the oesophagus to near the end of intestine, containing large number of larvae and eggs (Fig. 3a,c). Larvae: length of $332-481 \mu \mathrm{m}$, cranial end of body rounded and posterior end sharply pointed (Fig. $3 \mathrm{~d}$ ).

Male. Unknown.

Type Host. Micropogonias furnieri (Scienidae) juvenile from 7 to $23 \mathrm{~cm}$ standard length.

Site of infection. Inner opercular muscle.

Type locality. Ajó River, Samborombón Bay.

Prevalence and intensity. Size $2(6 \%, 1.00)$, Size $3(14 \%, 1.25)$.

Deposition of type specimens. Holotype deposited in the Helminthological Collection of the Museo de La Plata, Argentina (MLP-He 7081).

Etymology. The specific name, 'tahieli, is in honour of Martin's first nephew Tahiel Rodriguez Montes.

Histopathological analysis. The whitemouth croakers showed a macroscopic lesion characterized by a nodular pattern, in which was observed a subcutaneous parasite (Fig. 4a). The nematode was found coiled forming a capsule in the musculature of the operculum (Fig. 4a,b); microscopic examination revealed that its intestine contained fish red blood cells (Fig. 4c). Histopathological analysis of operculum by light microscopy showed that alterations in the muscle tissue were consistent with a chronic process. Histological evaluation revealed a core of caseous necrosis (Fig. 4d). This necrotic focus is characterized by acellular eosinophilic areas, surrounded by a granulomatous process. The muscle tissue was damaged and is replaced by dense connective tissue concentrically layered surrounding the nematode by way of the capsule (Fig. 4b). In addition, infiltration of numerous inflammatory cells (Fig. 4d) was observed within the infected tissue (i.e. eosinophilic granule cells, epithelioid cells and also sectors with haemorrhages).

\section{Discussion}

Philometrids are a diverse group of parasites with a worldwide distribution which exhibit a relatively high degree of host specificity and are characterized by the location of gravid females in the host 
(Moravec 2006; Moravec \& de Buron 2013). The genus Philometroides have been described only on the basis of females whereas conspecific males of numerous species remain unknown (Moravec, Walter \& Yuniar 2012).

In recent years, eight new species have been reported from Asia and North America, increasing the record to 19 parasites from freshwater and 12 from marine and estuarine fishes (Moravec $\&$ de Buron 2013; Moravec et al. 2015). In South America the only species of this genus, P. maplestoni was found in the abdominal cavity of Salminus hilarii Valenciennes, Characidae, from the Amazonas River in Brazil (Travassos et al. 1928).

According to the key provided by Moravec, Jassim \& Al-Salim (2012) from marine and brackish-water fishes, Philometroides tahieli sp. nov. is placed within the body length of gravid female is lesser than $50 \mathrm{~mm}$. Only the following four species are similar in size to the new species; Philometroides atropi (Parukhin, 1966) in Atropus atropos (Bloch \& Schneider) Carangidae, and Selar crumenophthalmus (Bloch) Carangidae, Philometroides oveni Parukhin, 1975 in Serranus hepatus (Linnaeus), Serranidae, Philometroides paralichthydis Moravec \& de Buron, 2006 in Paralichthys lethostigma (Jordan \& Gilbert), Paralichthyidae and Philometroides grandipapillatus Moravec \& Bakenhaster, 2010 in Caranx hippos (Linnaeus) Carangidae. Furthermore, P. atropi from South Asia differs to P. tahieli sp. nov., as it lacks the oesophageal bulb and has a markedly protruding cephalic region. Philometroides oveni from the Mediterranean Sea was found in the eye of $S$. hepatus and differs from P. tahieli sp. nov. as the oesophageal bulb is absent, the conformation of cephalic papillae differs and the simple bosses are
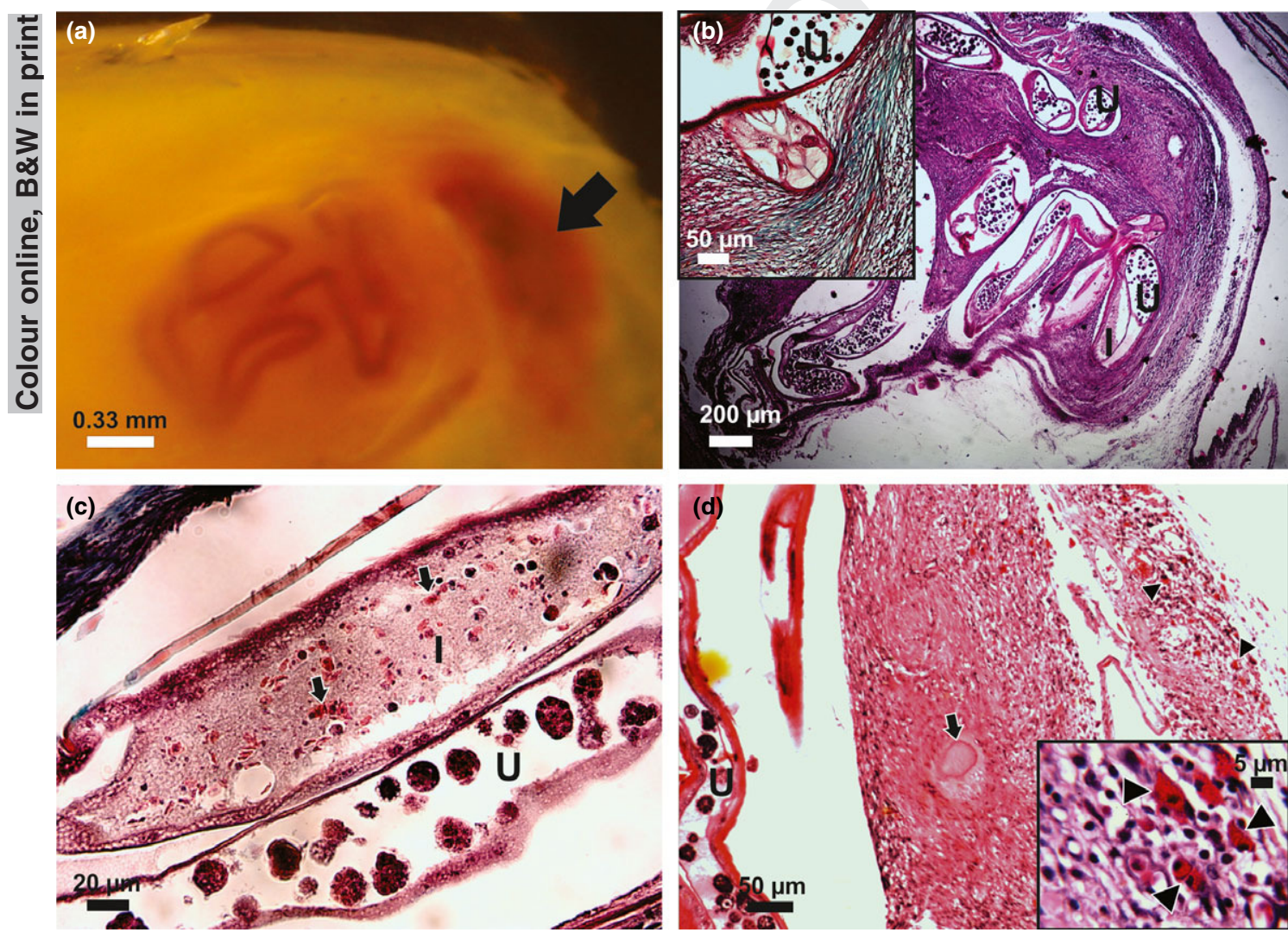

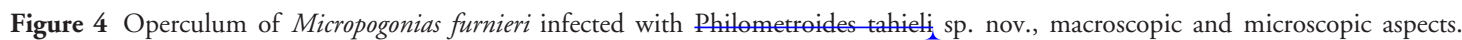
(a) Gross view of operculum showing a coiled subcutaneous parasite and a focus of caseous necrosis (arrow). (b) Transverse section through the musculature operculum. H\&E. Inset: detail of the nematode's cephalic end showing dense connective tissue concentrically layered. Masson's trichrome stain. (c) P. tahieli n. sp. intestine contained fish red blood cells (arrows). Masson's trichrome stain. (d) Caseous necrosis (arrow), probably the area where the parasite is attached. H\&E. Inset: Eosinophilic granule cells (arrowheads) such as inflammatory response of the host. H\&E. I, nematode intestine; U, uterus filled with eggs. 
not fused in longitudinal mounds. Philometroides paralichthydis, P. grandipapillatus and P. tahieli sp. nov. share an embossed body and the absence of caudal projections. Although $P$. paralichthydis was reported living in brackish-waters, it can be distinguished from this new species by the smaller size of gravid female, the presence of transversal and longitudinal mounds, the different host species and the infection site. Finally, P. grandipapillatus from a marine environment was found in the subcutaneous tissue and muscle from the host but has some features that can be distinguished from P. tahieli sp. nov.: a distinctive narrowed anterior portion of the body and conspicuously large cephalic external circle of papillae. Recently, Moravec et al. (2015) described a new species of Philometroides in Labeo rosae Steindachner, an African cyprinid fish, but this nematode parasite was found in the outer surface of operculum, and the morphological features are different of the species here described.

Data on the life cycles of philometrids are scarce but exhibit patterns associated with various factors, such as a season, fish size, gender and spawning activity (Moravec \& de Buron 2013). These nematodes have an indirect life cycle; the first stage larvae $\left(\mathrm{L}_{1}\right)$ are released into the water and are ingested by the intermediate hosts, usually copepods. In the host's haemocoel, the larvae molt up to the third stage $\left(\mathrm{L}_{3}\right)$, which is infective for fish (Moravec 2004). In our work, only juvenile fishes have been found parasitized; unlike adults, these live in estuarine environments. According to Hozbor \& García de la Rosa (2000), the copepods may be the main prey of smaller sized fishes.

The pathogenicity of the parasite is low in the natural environment, but lesions that are consistent with a chronic process can be seen. Lesions observed were associated with the gravid females present in the gill operculum and were correlated with the October to December occurrence of these stages in the annual life cycle of the parasite. The appearance of caseous necrosis suggests the presence of a locally acting substance, probably histolytic enzymes secreted by the oesophageal gland (Huazy 1978). As in other infections by Philometroides described by Huazy (1978) and de Buron \& Roumillat (2010), this nematode parasite is surrounded by a connective tissue capsule, with a vascularization increase in proximity of the capsule and the presence of fish erythrocytes in the intestine of the worms indicates these cells were ingested. Importantly, when the nematode parasites are located in the muscles controlling opercular movements they may induce mechanical damage.

In conclusion, a new species, $P$. tahieli, is only the second species described from brackish waters, and the second from South America. Philometrid nematodes are known to exhibit a relatively high degree of host and site specificity (Moravec \& Justine 2014); the new species can be identified by the location of gravid females in the host; the site of infection (inner surface of the operculum) and the brackish environment in which it is found. A combination of morphological features including the presence of an anterior oesophageal bulb, bosses on the surface of the body, presence of the transversal mounds and the position of the cephalic papillae allow us to erect $P$. tabieli sp. nov. However, to evaluate disease risks in cultured fish further studies are necessary to increase the knowledge on diverse aspects, including the identification of males, and the biology, ecology and pathogenicity of the parasite.

\section{Acknowledgements}

We want to thank Marcia Montes for the drawings, Mariela Theiller for taking the SEM images, Emilio Topa for the histological preparations and Daniel Tanzola for the juvenile whitemouth croaker of 2008 and specially to Joanna Browne native English speaker from Griffith School of Environment and Australian Rivers Institute - Coast and Estuaries and Marine Invertebrates, Melbourne Museum, Australia for editing the final version of the manuscript. This work was partially funded by a research grant from the Consejo Nacional de Investigaciones Cientificas y Tecnicas (CONICET PID 0257) to SRM.

\section{References}

de Buron I. \& Roumillat W.A. (2010) Histopathology of two philometrid parasites of the southern flounder, Paralichthys lethostigma. Journal of Wildlife Diseases 46, 277-282.

Bush A.O., Lafferty K.D., Lutz J.L. \& Shostak A.W. (1997) Parasitology meets ecology on its own terms: Margolis et al. revisited. Journal of Parasitology 83, 575-583.

Carozza C. \& Hernández D. (2014) Estimación de la Captura Biológante de corvina rubia (Micropogonias furnieri) mediante delay diference model para aguas del Rio de la Plata, ZCP y adyacentes al norte de los $39^{\circ} \mathrm{S}$. Informe 
Técnico del Instituto Nacional de Investigación y Desarrollo Pesquero 14, 1-15.

Carozza C.R., Lasta C., Ruarte C., Cotrina C., Mianzan H. \& Acha M. (2004) Corvina rubia (Micropogonias furnieri). In: El Mar Argentino y sus Recursos Pesqueros. Los Peces Marinos de Interés Pesquero. Caracterización Biológica y Euluación del Estade Explán (ed. by R.P. Sánchez \& S.I. Bezzi), pp. 255-270. Publicaciones Especiales del Instituto Nacional de Investigación y Desarrollo Pesquero, Mar del Plata.

Cousseau B. \& Perrotta R. (2004) Peces Arom Biología, Distribución, Pesca, pp. 167. Instituto Nacional de Investigación y Desarrollo Pesquero, Mar del Plata, Argentina.

Deardorff T.L., Overstreet R.M., Okihiro M. \& Tam R. (1986) Piscine adult nematode invading open lesion in a human hand. The American Journal of Tropical Medicine and Hygiene 35, 827-830.

Díaz de Astarloa J.M., Carozza C., Guerrero R.A., Baldoni A.G. \& Cousseau M.B. (1997) Algunas características biológicas de peces capturados en una campaña costera invernal en 1993, en el área comprendida entre $34^{\circ}$ y $42^{\circ} \mathrm{S}$ (Atlántico Sudoccidental) y su relación con las condiciones ambientales. Informe Técnico del Instituto Nacional de Investigación y Desarrollo Pesquero 14, 1-35.

Haimovici M., Pereira S.D. \& Vieira P.C. (1989) La pesca demersal en el sur de Brasil en el periodo 1975-1985. Frente Marítimo 5, 151-161.

Hozbor N.M. \& García de la Rosa S.B. (2000) Alimentación de juveniles de corvina rubia (Micropogonias furnieri) en la laguna costera mar chiquita (Buenos Aires, Argentina). Frente Marítimo 18, 59-70.

Huazy L.S. (1978) Lesions associated with Philometroides huronensis (Nematoda: Philometridae) in the white sucker (Catostomus commersoni). Journal of Wildlife Diseases $\mathbf{1 4}$, 401-408.

Kuroda T., Murayama T., Imai J., Horii Y. \& Nawa Y. (1991) The first record of Philometroides sp. vomited from a man in Japan. Japanese Journal of Parasitology 40, 599-603.

Lasta C.A. \& Acha E.M. (1996) Cabo San Antonio: su importancia en el patrón reproductivo de peces marinos. Frente Marítimo 16, 29-37.

Moravec R. (2004) Some aspects of the taxonomy and biology of dracunculoid nematodes parasitic in fishes: a review. Folia Parasitologica 51, 1-13.

Moravec R. (2006) Dracunculoid and Anguillicoloid Nematodes Parasitic in Vertebrates, pp. 634. Academia, Prague.
Moravec R. \& de Buron I. (2013) A synthesis of our current knowledge of philometrid nematodes, a group of increasingly important fish parasites. Folia Parasitologica 60 , 81-101.

Moravec F. \& Justine J.L. (2014) Philometrids (Nematoda: Philometridae) in carangid and serranid fishes off $\mathrm{New}$ Caledonia, including three new species. Parasite 21, 1-16.

Moravec F., Jassim A.A.R. \& Al-Salim N.K. (2012) Philometroides acanthopagri sp. nov., a new philometrid (Nematoda, Philometridae) from the musculature of Acanthopagrus latus (Sparidae) from marine waters of Iraq. Acta Parasitologica 57, 372-377.

Moravec F., Walter T. \& Yuniar A.T. (2012) Five new species of philometrid nematodes (Philometridae) from marine fishes off Java, Indonesia. Folia Parasitologica 59, 115-130.

Moravec F., Halajian A., Tavakol S., Nyagura I. \& LuusPowell W.J. (2015) Philometroides khalili n. sp., a new philometrid nematode (Philometridae) from the operculum of the cyprinid fish Labeo rosae in Zimbabwe. Helminthologia 52, 113-117.

Norbis W. \& Verocai J. (2005) Presence of two whitemouth croaker (Micropogonias furnieri, Pisces: Scianidae) groups in the Rio de la Plata spawning coastal area as consequence of reproductive migration. Fisheries Research 74, 134-141.

Otero H. \& Ibañez P.M. (1986) Abundancia relativa de la corvina rubia (Micropogonias furnieri): modelos de producción excedente. Publicaciones de la Comisión Técnica Mixta del Frente Marítimo 1, 341-350.

Plaul S.E., Montes M.M., Barbeito C.G. \& Martorelli S.R. (2013) Morphological aspects and histological effects of the attachment organ of Parabrachiella sp. (Copepoda: Lernaeopodidae) on the grey mullet, Mugil liza Valenciennes. Journal of Fish Diseases 36, 853-859.

Schäperclaus W.- (1992) ?????????? . In: Fish Diseases, Vol 1 and 2, 5th edn (ed. by W. Schäperclaus, H. Kulow \& K. Schreckenbach), pp. 1398. U.S. Depant of the Interior and the National Science Foundation, Washington, DC. Amerind, New Delhi.

Travassos L., Artigas P. \& Pereira C. (1928) Fauna helminthological dos peixes do água doce do Brasil. Archivos do Instituto Biologico (Sao Paulo) 1, 5-68.

Received: 1 August 2015

Revision received: 20 October 2015

Accepted: 20 October 2015 